\title{
Swimming with Tuna: Human-Ocean Entanglements
}

\author{
Elspeth Probyn
}

We're on a pontoon somewhere in the middle of Boston Bay, at the bottom of the Eyre Peninsula in South Australia - the birthplace of tuna ranching. The fairly short ride over in the Adventure Tour boat was enough to churn my stomach, and the sideways swaying of the pontoon isn't helping my general queasiness. I can handle anything if I am in water. One of my favourite pastimes is to swim straight out into the middle of the ocean, but this has been curtailed by being in South Australia, home of the great white pointer shark and assorted cousins. I tend to swim on the water rather than in water. Analogous to a critique levelled by Aboriginal people about how whites walk through country rather in it, I have too often floated above the densely populated world of the sea. It's a onesided view of the world that we need to re-address if we are to do justice to the immensity of human-ocean entanglements.

Steve, our handsome tour guide, has given us all sorts of information gathered over some 20 years of his life as a prawn trawler man, deep sea fisherman, and now occasional guide on his mate, Matt Waller's tour boat. Matt got out of fishing to set up Adventure Tours, a fully eco-offset enterprise, which takes tourists from around the world to see at first hand tuna, and sea lions. He recently has added swimming with great white sharks - which is beyond me. Matt is cleareyed about the difficulties facing the fishing industry, which includes the fierce and ultimately ecologically untenable competition for dwindling world-wide stocks, and long and dangerous work for a family man. But he also remembers vividly what he calls the 'high of fishing'. Those were the days when the fish were easy and Port Lincoln would be full of young hard working guys with lots of money ready to party. Money doesn't flow as easily these days, and the town is besieged with worries about the future of the fisheries and of fishing itself. Matt himself is in a fierce price war with another outfit that coined the name, 'Swim-with-the-tuna', some years after Matt had initiated the idea. Such are the emotions that normally voluble fishers around town go quiet when I mention the feud.

Out at sea our boat pulls up next to a floating enclosure-heavily protected against the pirates who will steal the fish if they can. We've also reached the pinnacle of our tuna tour and here we are with a pen of some 300 juvenile Southern Bluefin tuna. The idea is now to jump in with them - as they speed for pilchards. Apparently they can go from 0 to $70 \mathrm{~km}$ faster than a Porsche and 
with better brakes. Steve and his young helper show us how the tuna rise to the surface when they are fed. He has several crates of frozen pilchards, which he tries to get us to handle. He shows us how to carefully hold the pilchard from its tail above the water so that the tuna don't get your hand in their haste for food. Commercial pens will hold a couple of thousand tuna and they consume huge amounts of feed - sometimes whole blocks of frozen feed are placed in the pens. Even relatively small operators will spend \$3 million in pilchard feed a year. Unlike salmon farms, the tuna farms in the Eyre Peninsula apparently don't use antibiotics, and because they are so far out there are fewer problems with the nitrate in their faeces polluting the water. ${ }^{1}$

While the others mill about and drag on wetsuits, I dive in. I can feel the fish beneath my feet. Then the young boy helping out on the tour chucks pilchards at me. Sure enough these sleek beauties zoom towards me at top notch, get the fish and then stop just short of my nose. It's an eerie introduction to meeting tuna. I eat several tins of their cousins each week-mainly skipjack; Bluefin are much too expensive to eat any way but raw or slightly seared. The chances are slim that you can eat Bluefin tuna in Australia given the massive export to Japan. Within 16 hours of being speared in the head in Boston Bay, a Southern Bluefin tuna will be delicately carved and served to discerning customers at a sushi bar in Tokyo.

Diving and floating miles above the bottom of the sea, dodging pilchard debris and flirting with passing tuna - is this a commingling of human and tuna, or just the pretty face of an industry out to render extinct these magnificent beasts of the ocean?

It's my aim to further an argument that recognises and materialises human-fishwater entanglements, or what Michel Callon calls 'a network of relationships in which social and natural entities mutually control who they are and what they want'). This is a challenge on many fronts. Focusing on the proximities of natural and social entities threatens to veer into anthropomorphism-how can I but project onto the tuna my thoughts about what they are? At the same time it can radically challenge what we know about the limits of human and nonhuman existences. Bringing this abstract (and well-trodden) framing down

\footnotetext{
1 The pros and cons of aquaculture are unfortunately too vast to do justice to here. Suffice to say that there are heated arguments on both sides, and also that aquaculture covers an immense variety of practices, and also spans history: small scale pond aquaculture has been used in Asia for millennia and in the work, for instance, of the WorldFish Centre headquartered in Malaysia, continues to promote aquaculture as the best means to feed the poor in developing countries, see $<$ http://www.worldfishcenter.org/wfcms/HQ/article. aspx?ID=827>. Accessed 8 June 2010. On the con side, badly managed fish farms have been responsible for contaminating wild stocks both genetically and with disease, and contributing to the pollution of oceansestimates about the faecal residues compare one fish farm to a town of 60,000. The tuna farmers of Port Lincoln as well as all the town's inhabitants remember vividly a catastrophe in the mid 1980s when for some reason the ocean currents quickly changed and all the farmed tuna died in a few short hours.
} 
to earth, swimming with tuna provokes questions about their conditions of existence. David Goodman's take on the enmeshment of social and natural is straightforward: 'to explore nature-society co-productions' (34). While I may have learned a fair amount about tuna through reading about the various aspects of their 'life' - from the analyses of fishing trade through to what makes their flesh so delicious - being in their milieu (or at least their medium, given that they probably prefer not to be in pens) raises different questions. And as I wallow in an experiment where humans seem to be at the beck and call of the tuna ('feed me'), I am viscerally out of my domain. Indeed I feel very green. It is a greenness that Gisli Palasson, the Icelandic anthropologist, captures in his understanding of seasickness, which he says can be seen as a kind of culture shock - indicating a lack of 'emotional and physical manifestations of mastery and enskilment' (905).

\section{Eating into the global}

There is perhaps no area where the global inserts itself into the intimate and emotional lives of people than in the realms of food production and consumption. The gamut of emotions that coincide with eating run from disgust (Darwin's 1872 example of visceral disgust involved dried meat and a 'native') through to the sublime of oyster eating (most beautifully conveyed by M.F.K. Fisher; see also Probyn, 'Interests'; Kurlansky).

While the worldwide circulation of food and people has spectacularly accelerated through the ever-increasing complexity and reach of global technology, supply chains and logistics, food has long travelled and connected very different peoples and land. As the economic historian Harold Innis argued in the 1920s and 1930s, staples such as fish were integral to the development of the economic world as we know it. Innis' classic thesis on the cod fisheries of the Canadian Maritime (1940), demonstrated the far-reaching effects of one staple economy. From the sixteenth century onwards, the Grand Banks of Newfoundland became a battleground between the Old World powers: 'Cod from Newfoundland was the lever by which she [England] wrested her share of the riches of the New World from Spain' (52). In Innis' terms, food staples caused empires to rise and fall as their routes rearranged the political economic face of the world.

The role of food has continued to be the site through which global politics are played out in local and highly emotional ways. The field of food, understood in Bourdieu's sense as a field of forces and a field of struggles (30), is also a minefield, which pits ethnicity, gender, globalisation and class privilege. Recently, 'feelgood' food politics have increased in many sections of the developed world, with the rise of farmers' markets and other 'alternative' food outlets in most urban 
Western regions. This plays out in public debates and at times polemics about 'food miles' and carbon footprints of what we eat. As I've argued elsewhere (Probyn, 'Interests'), this has a tendency to become a fetishization of the local, which can lead to a rather parochial politics of food. Michael Winter calls this 'defensive localism', which he sees emerging from a mixture of 'parochialism and nationalism' (30). Class, gender and ethnic privileges and distinctions are often overlooked in this putative progressive food politics. One of the original founders of the Italian Slow Food movement, Fabio Parasecoli, reminds of us some of the shortcomings of some food politics. His critique focuses on the North-South divide, as well as the gender bias in the rhetoric of Slow Food:

In a world doomed by pollution, biological homogenization and globalization, women are transformed into the defenders of the holy environment that constitutes the family. Their role would be to stay at home and protect it against the evil forces that haunt our present. (38)

Julie Guthman's critique of the neo-liberal force of such politics has incisively revealed the moralistic tone and the ethnic- and class-blindness of much of the 'alternative' food circles ('Neo-Liberalism'; 'Can't Stomach'; 'Fast Food'). Writing about the rise of organic from the 1980s in northern California, of which the most successful product is organic salad mix or what the growers call 'yuppie chow', Guthman questions the motivation of 'those whose moral sensibilities increasingly privileged environmental concerns over social ones' ('Fast Food' 54). The key thrust of her critique concerns the ways in which the privileged have taken on the congratulatory mantle of self-reflexivity in eating at the expense of those others who are said to lack the cultural capacities to know that local, organic, slow food tastes better.

Like many feminists much of my own work has been on questions of subjectivity and was prompted by Adrienne Rich's call to 'begin ... with the geography closest-in' (9). I responded to Rich's politics of location and the politics of positionality with detailed descriptions of my body. That this body, my body, had an overly reflexive relationship to eating led me into analyses of anorexia and control ('The Anorexic') and then away from food and into sex (Outside) and then back to food and sex (Carnal). Working through a Foucauldian and then a Deleuzian frame, I sought to examine subjectivity obliquely through eating.

However, I want to go beyond my previous work, and also a prevalent feminist focus on questions of human sovereignty and agency under the regime of neoliberalism. With Gerry Pratt and Victoria Rosner I want to go 'beyond the usual register of map-reading' (at which I am atrocious) to try to convey the sounds, smells and tastes of the material ground of what we eat (17). Drawing on fieldwork, I want to consider how micro and very intimate practices intersect with the macro forces of supply chains and foodways - in many ways similar 
to what Ian Cook calls 'geographies of food: following'. As Terry Marsden and Jonathon Murdoch argue forcefully about the complexity of global-local food forces, this is 'to recognize that some food spaces are integrated into global systems of food provisioning while others are integrated into regionalized and localized relations' (1-2).

Following tuna, following fishers ... the argument I am trying to construct (and this is very much a work-in-progress) of necessity takes me away from debates about representation. In geography, as Sarah Whatmore and many others have argued, the very matter of life and the planet need to be rethought. Whatmore argues that 'cultural geographers have found their way (back) to the material in very different ways that variously resonate with ... the most enduring of geographical concerns - the vital connections between the geo (earth) and the bio (life)' (601).

You could call this an alimentary ecology where, as Deborah Bird Rose and Emily Potter have respectively argued: 'Matter is recognised as having the ability to "express" itself in complex and creative ways' (Rose cited in Potter). The research that fuels my interest builds on ways of thinking intimacy, emotions and globalisation in a different voice, and is part of a larger project on how the relationships between taste (consumption) and place (production) are being rearranged in the globalised food system. ${ }^{2}$ Here I want to explore taste in its various guises, in a conscious move away from the dominant sociological framing of taste as first and foremost, if not always, about social distinction. As with Whatmore's approach, I will employ a self-conscious act of storying', what she calls 'an envoy of the recuperation of "materiality"' (601), or what elsewhere I call a rhizo-ethology of bodies (Probyn, 'Eating for a Living'). This casts research as a wending through ethnographic observation and the stories told by different individuals. It places me as a myopic mole burrowing along various pathways and networks, occasionally morphing into the stance of meerkat surveying the topography. My concern here is what I am calling the interests of taste and place. Taking 'interests' as both economic and social, and as also driven by curiosity, the etymology of 'interest' refers us to the 'inter-esse', and the materiality of the different forms of being in-between. Isabelle Stengers, the Belgian feminist philosopher of science, uses the etymology of interest to talk 'of bearing witness to the many aspects of entangled slow stories'. There are just so many interesting slow stories about the place of taste and the tastes of places. Telling them, listening to them and passing them on are part of the process whereby we relearn to be interested in the material connections of taste and place. This is for me one aspect of a crucial ethics of eating, of taste and place.

2 Elspeth Probyn, 'Taste and Place: The Transglobal Production and Consumption of Food and Drink.' Australian Research Council Discovery Project. 2009-2011. 


\section{Tuna tastes}

Let's go back to the tuna. So there I am or rather there we are splashing around together in water dense with pilchard-feed - a strange mixture of human and non-human swimmers. The sardines are an integral part, even if sardine fishers may feel like handmaidens to the economies of tuna. The tuna farms take $98 \%$ of the sardine and pilchard quota to fatten up the fish. It's a strange business whereby one fish goes to feed another. The South Australian Sardine Fishery is South Australia's largest volume single species fishery. In 2008-09, 26,692 tonnes of sardines, with a value of \$16,331,000 were harvested. ${ }^{3}$ Apparently 25 pounds of sardines go into every pound of farmed tuna. ${ }^{4}$ Despite being named one of Oprah Winfrey's 25 'super foods', ${ }^{5}$ it is tough for the sardine industry to break away from their ties with the tuna farms. When I talked to one veteran about the possibility of setting up a side venture, he shrugged in despair. 'What would be the point?'

So in every way, tuna are in a league of their own - the fastest predators in the sea, they travel huge distances in their annual migration. Southern Bluefin can grow to 200 kilos, whereas their Northern Bluefin cousins get even larger - up to 700. The Southern Bluefin spawns in the Indian Ocean near Java and from there the juveniles make the trip to the Western coast of Australia and around through to the Great Australian Bight. They are amazing swimmers, and in fact have to keep moving because they get oxygen from water flowing across their gills. In their long journeys they can speed along at up to $70 \mathrm{~km}$ per hour when their fins retract into their bodies, and eyes close to make them into the most perfect aqua-dynamic eating-swimming-breathing machine. For me and for many, this is what makes tuna so special. For fisheries management they pose a particular problem in that they routinely range across the jurisdictions of so many countries. As Robin Allen argues for the FAO, 'Free riding states would be able to enjoy the benefits of the efforts of conservation made by responsible states' (2). For me, they encapture globalization itself: moving widely around the world, they are landed in quite specific economic relationships. Tuna also starkly sum up the quandaries of food production and consumption: as the top of their food chain, they eat anything that goes - squid, rockfish and sardines.

\footnotetext{
3 <http://www.environment.gov.au/coasts/fisheries/sa/pilchard/pubs/sardines-re-assessment.pdf $>$. Accessed 17 April, 2010.

4 See Sustainable Sushi website: <http:// www.sustainablesushi.net>. Accessed 28 October 2011.

5 See <http://www.oprah.com/food/The-Superfood-Menu>. Accessed 10 June 2010.

6 This unnamed sardine fisher was deeply pessimistic about the future of fishing — and in fact was planning on selling up and moving away. Later, however, at an event in Adelaide I happened upon sardines for humans. Jim Mendolia founded the Fremantle Sardine Company to further the dream of his father, Frank - a fisher originally from Sicily whose dream it was to establish a sardine processing plant in Fremantle, Western Australia. Jim has ties with the Port Lincoln sardine fishers and takes some of their catch, and turns them into lovely salted and marinated fillets for the Asian markets, and now gradually for Australian consumers.
} 
There is a great deal of debate about whether Northern or Southern Bluefin taste better but as we'll see because of human-aqua-cultures, the taste of and for tuna is changing. But what is undeniable is that it really would be better for all if we were to eat fish lower on the food chain - in other words, we should be eating the tuna's food.

While humans have been eating them for millennia the techniques and technologies that mediate human-tuna interaction have changed considerablyleading to huge increases in tuna's value, and of course massively decreasing their stock. In Australia, coastal Aboriginal people on the southeastern part of NSW and in the Eyre would have caught tuna using baskets when they came into shallow waters. The baskets on display at the Museum of South Australia look very much like prototypes of the purse-seine nets now used commercially. It is only relatively recently that Westerners have taken to tuna. The Eastern seaboard of North America had long had large stocks of tuna but until the Japanese came calling in the 1960s and 70s they were seen as inedible trophy fish. People would catch them, have their photo taken with the dead fish and then dump the tuna in the landfill. That all changed when in the 1970s Japanese airlines began to experiment with loading tuna from the Eastern seaboard of North America to fill their empty cargo holds after delivering electronic goods to American markets. As Sasha Issenberg describes it, tuna went from being pet food to one of the most valued natural resources in the space of two decadesan event 'that has little parallel in history' (xii).

The distribution of the tuna fisher population in Australia is historical, ethnic and geographical. The Italians (the Puglisis) rule the southeastern coast from Ulladulla to Eden, NSW, and the Croatians own the sea turf in the Eyre Peninsula. In Ulladulla there have been Puglisis in fishing from before WWI when the first family emigrated from Sicily first to Wollongong and then followed the fish down the south coats of NSW. Waves of familial migration consolidated the family's name among fishers, although as several of the cousins told me, there was considerable resistance among the Anglo-Celt and primarily farming community to their acceptance.

There is a curious but strong bond between Port Lincoln, which Matthew Flinders found as he was charting the coast in 1802, and the tiny town of Kali in what is now Croatia. But I'll let the tuna fishermen I interviewed tell the tale. ${ }^{7}$

7 The interviews were conducted in Port Lincoln over three weeks in February 2010, and then again over two weeks in March 2011. Unless noted, I have with their permission used real names. My thanks to Len Stephens, the CEO of the Collaborative Research Centre on Seafood for his help in contacting people in the industries. And of course my thanks to those I interviewed. The interviews were open-ended, and lasted for one to two hours. 
First off is Dinko Lukin, one of the original tuna barons (Port Lincoln is widely known as the capital of Australian millionaires made nearly exclusively from tuna). I met up with Dinko at his factory just outside of town, which certainly doesn't look like a millionaire's pad. Dinko is now in his late 70s, and he arrived in Melbourne from Croatia in the 1950s. I was early, so I wandered down to the water to look at the 'resting' farming pens. These are the commercial ones, much bigger than the one I swam in. Pelicans and other seabirds line the pen, hopefully waiting for some action.

Back at his office I meet Dinko and a young woman-both have stunning blue eyes. It turns out that the young woman is his second wife and from Thailand. We sit and he looks at me intently - soon it turns out that he is a bit of a charmer, and has me girlishly giggling in no time. I am to find out that the tuna boys are a seductive lot - something to do with those blue eyes and intensity, and who knows maybe power. In the 1960s Dinko built his first tuna boat, the Orao, which held a tiny crew of seven. This was in the days that tuna were long-lined and poled. The Japanese had been long lining in the Java where they spawn and into Australian waters since the 1950s. This requires large boats, which subsequently became the infamous 'factory ships' when the Japanese came up with the technology to freeze fish on board at minus 60 degrees. In the early 1960s the Japanese boats would catch over 81,000 tonnes of SBT. By comparison, in 2005 the quota set by Commission for the Conservation of Southern Bluefin Tuna for all member countries was 14,000 tonnes although it is estimated that the total global catch was more like over 21,000 tonnes. The fishermen in Port Lincoln are stewing over this year's quotas, which reduced the Australian allowable catch by $25 \%$, down to 4,015 tonnes. Several of the big operators complain that they can fulfil their allowable catch in a day or two of fishing a year.

Back then to Dinko's little boat, which was limited to surface catches with lines and poles. The tuna were caught on line and then hoisted up by pole. It didn't do much for the tuna, who were bruised in the operations. That's unthinkable now that the price for perfect fresh tuna can be over 600 dollars per kilo at the Tsukiji markets. The work was hard on the men too-you can imagine what they faced in the waters of the Great Bight. Dinko's son, Dean, was a testament to the muscles required - he was the first and only Australian ever to win an Olympic gold in heavy weightlifting in the 1984 Olympics, and was said to test his talent in the famous Tuna Toss, hosted by John West at the Port Lincoln Tunarama.

As Dinko describes it, life was pretty good in those early days. 'The crew did not feel any fear as they faced the strongest elements that a god created.' Not only didn't they fear the elements ('I'd never give one inch to the weather'), they preferred going out in bad weather. It was said by his crew that the Oroa was 
a magic boat, often hauling in huge amounts of tuna when no one else could. Later magic was aided by technology with the use of spotter planes, which fly low over the seas reporting down to the boats on the location of the large schools that swim close to the surface.

With the downturn of stocks in the 1980s, the fish seemed to have disappeared. According to Greenpeace, ${ }^{8}$ by the end of the 1970s 'overfishing had depleted the stocks to $2.5 \%$ of the original population'. Long lining is seen as responsible for the worst of by-catch. Now mainly used by the Japanese (according to nonJapanese sources, that is), these boats work 24 hours a day laying out fishing lines of up to 100 kilometres long, each carrying up to 3000 baited hooks. Blaming long-liners and 'the Japanese' for the downfall in stocks doesn't bear much scrutiny. While, as I discuss later, the Japanese taste for raw tuna has spread around the world, and Japan remains the hub for world prices on sashimi grade and usually Bluefin tuna, there is considerable debate about the pitfalls of fishing methods within Japan. The Tokyo-based Organisation for the Promotion of Responsible Tuna Fisheries (OPRT) has been quite successful in bringing together the large tuna long liners from around the world. According to World Fishing \& Aquaculture, a UK based site for commercial fishing, OPRT has managed to bring on board $90 \%$ of the world's large scale tuna long liners over 24 metres in length in 12 countries. One of the significant problems in steering the industry towards better and more sustainable fishing is the number of boats that sail under Flags of Convenience (FoC) - which is to say those that take on flags from smaller and non-member states, who routinely disregard national and international attempts to regulate the industry. Japan for its part has committed to not buying fish from such vessels, however the routes of fish sales are circuitous ('Japan Urges'). ${ }^{9}$

The purse seiners that travel the world are hardly ecologically correct either, and in fact they scope up juvenile tuna to the detriment of all concerned - the fishers make much less money from small Bluefin or other potential sashimi grade tuna because of their lack of the distinguishing and sought after fat on the mature fish, and of course catching juveniles can only lead to the further decimation of the stock.

That is, if the smaller fish are merely turned into canned tuna. This is where Dinko enters the story again. When the quotas hit in the 1985, Dinko was the

8 <http://www.greenpeace.org/australia/issues/overfishing/our-work/save-our-tuna>. Accessed June 10, 2010 .

9 For a focused analysis of Japan's tuna industry, and its links to development strategies in the Pacific, see Kate Barclay. As Barclay and others have pointed out, fish and fishing is particularly important to Japan given its very limited capacity to feed itself from terrestrial sources. Historically this has produced very close relations between the government and Japanese fisheries (Barclay and Koh). For another view of the special relationship that fish has in Japan, see also Bestor's ethnographies of sushi in Japanese culture as well as his account of Tsukiji Fish Market ('When Sushi Went Global' and Tsukiji). 
first to come up with the idea of cultivating tuna. Now the idea of catching the tuna in purse seine nets is practiced the world over. The nets round up the tuna a bit like cattle are wrangled, and very slowly and carefully transfer them into sea cages and then slowly drag them back to port. Back then everyone thought that Dinko was mad. But in fact the idea made absolute sense: catching a smaller tuna and then feeding it up 'effectively doubled the fishermen's quota as the limit on their catch was determined by the weight of the fish caught in the wild, with any weight gained in captivity a bonus' ('About Dinko').

As I talk to Dinko, we travel through his stories of glory, and of his numerous 'firsts'. But underlying there is another story-one of migration, of families torn apart in divorce and greed, and of sadness at the end of his life. His son, Dean, apparently no longer talks to him and the sign 'Dinko and Sons' has had the last bit painted through. As I leave he asks me if I like tuna. 'Yes' I say a little hesitantly because I'm ready to leave now. He directs me to the back office, which looks like a junk yard of old computers, equipment and boxes, and he tells me to climb up and get a box of what is labeled John West tuna in brine. When I pass it to him he gives it back saying proudly that the box contains unmarked tins that are Southern Bluefin Tuna in oil-yum, we've been eating the most expensive tuna sandwiches ever since. I leave with my tins of tuna, and as I say goodbye he looks at me closely as his wife joins me. 'She is older than she looks - 45- she must be your age.' I laugh at the compliment - she looks 20 and I look my age.

\section{Watery commons}

Released from the magnetism of an aging tuna baron I can ponder more closely the backdrop of jurisdiction and fisheries management, which frame the tuna industry now. A meeting with a very senior fisheries expert puts the boasting into perspective. He reminds me of what he calls 'the first principles', the first of which is that the ocean and all within are common resources. This, of course, recalls Garrett Hardin's infamous essay, 'The Tragedy of the Commons'. In 1968 Hardin, a genetic biologist, debated the consequences of population growth in terms that are instructive and provocative:

It is fair to say that most people who anguish over the population problem are trying to find a way to avoid the evils of over-population without relinquishing any of the privileges they now enjoy. They think that farming the seas or developing new strains of wheat will solve the problem-technically. (1243)

In other words, we want to eat our tuna too. Hardin's response wends through a critique of the United Nation's Universal Declaration of Human Rights, 
which a year before had framed the family - and most crucially its size - as 'the natural and fundamental unit of society' (cited in Hardine, 1246), to which Hardin declares that the 'Freedom to Breed is Intolerable'. He finishes with the argument that 'social arrangements that produce responsibility are arrangements that create coercion, of some sort.' Hardin's pithy phrase is: 'Mutual Coercion, Mutually Agreed Upon' (1247).

This is precisely the structural framing of fisheries management, which according to my senior bureaucrat began in 1968. The law of the commons comes down to enforcing measures of in-put versus out-put - as he put it, it is about controlling the number of dead fish. In the case of Australia, fisheries management has been set up as a kind of proxy custodian to ensure some hope that extraction will be balanced by regeneration. In-put control sought to stem the diminishing stock by controlling the size of nets, and delimitation of fishing grounds and seasons, whereas out-put control is legislated through the quota system. The logic behind an individual quota system is that by making the commons into 'owned' or rented patches of sea, it is in the self-interest of the fishers to preserve stocks. As a tool of conservation it is hardly perfect: as Palasson and Helgason argue, it can also be an element of privatization. However, in some ways it removes competition - if, as happened last year, you catch your yearly quota of SBT in a couple of days, that's it. The yearly cuts to quotas have also substantially reduced the fishing fleet. For tuna it went from 250 tuna operators to 22, all located in Port Lincoln.

\section{The poster boys of tuna}

I next meet with the younger generation, which according to Christian Pykethe SA Sardine Industry Association's executive officer-are the best skippers out, with a depth of 'enskilment' and tacit knowledge passed on from father to son-but never to daughters: women are believed to be unlucky on board.

I meet Rick Kolega and Semi Skojarev at the bar at the fancy new marina outside of town. The marina was built by number one tuna baron, Sam Sarin. Number two, Tony Santic, puts his money into horses including the multiple Melbourne Cup winner Makybe Diva (of whom there's a statue in town). Number three is Hagen Stehr, who as we'll see spends his money on science. In terms of their quotas, Sarin owns a bit over 2000 tonnes, or $40 \%$ of the Australia quota, Santic has 1,200 and Stehr, 700 tonnes. It's hard to give an exact account of how much that is worth as the price fluctuates so much, but let's say it's between $\$ 110,000$ and $\$ 180,000$ per tonne. Rick and Semi's company SEKOL has $10 \%$, so they're not starving either. 
In fact no one is. From the perspective of the marina, the place is flush with yachtsmen, trophy wives, and money. Rick and Semi also come from Kali, and are keen to recount their parents' stories - Semi's father is Dinko's first cousin. Sitting with a glass of wine facing the mansions built around the marina, they seem to relive the past. Rick's parents fled Soviet Croatia/Yugoslavia by boat to Italy, were interned in Italy and then escaped by foot to Paris. From there they managed to get on a boat to Sydney and after several camps there they made the trek to Port Lincoln. Semi's father got caught trying to get out of Kali, but tried again and again until he too arrived in Sydney to eventually find his way to the tuna. Both men have been on the boats since they were teenagers but in the late 1980s they took advantage of the introduction of quotas to buy and merge with others to form their company, which like all the others is $95 \%$ focused on the Japanese market. With Dinko and other Croatian-Australians, they went back to post-Soviet Croatia to set up tuna farming there. Some see this technological transfer as overly patriotic - and to the wrong country. Others comment on the volatile mix of ethnicities and egos.

As far as I can see Rick and Semi are nice guys who seem to hold the community close. While there is worry about generational continuity, the old adage of the second generation squandering the wealth doesn't seem to hold. Semi and Rick are first and foremost businessmen - although they still do go out on the boats, and you can see how much they love the ocean, their priority is diversifying their company. They know it is important to develop the local market, and that 'it's nice to know the product stays in Australia' but add as a caveat if the prices are right.' They're also fed up with competing with foreign imports into Australia. For instance, the prawn market is dominated by Thai and Vietnamese product. $^{10}$

Arguably the most famous face in tuna is that of Hagen Stehr, the owner of Clean Seas, which is now experimenting with breeding tuna on land. Stehr is a larger than life type of guy - he slipped off ship as a member of the Foreign Legion, fell in love with a local girl, and made his first million in ways that don't get talked about - much. Since then he has poured millions into a joint venture with the Japanese and Kinko University. The idea is that tuna larvae can be bred into fingerlings at the Arno Bay site, which then can be raised into fully-grown fish. It's beginning to happen but for many it is in the realm of science fiction. However Kinko University and its affiliated company A-Marine Kindai are already selling their fully 'artificial' tuna, which comes 'with an "authenticity declaration" covering its life history, from its 20 days of gestation to its diet

10 Aquaculture in Thailand and Vietnam is now a huge enterprise with many worried about the sustainability of the industry. While aquaculture has been practised in Asian countries, and especially China, for millennia there is now serious concern about the havoc it is wreaking on small-scale fishing communities. 
in an open-water facility to the material on netting surrounding it' (Barron). They are of course tiny compared to the big tuna brokers - it comes as a bit of a surprise that Mitsubishi is one of the world's biggest Bluefin tuna brokers.

\section{Entangled slow stories and fast fish}

So far I have presented the merest tip of an iceberg of information. The salient points remain, and they are all emotional: is eating Southern Bluefin tuna sustainable? To whom does it matter and why, and where? As I've sketched out, tuna is the lifeblood of Port Lincoln. Although it is estimated that less than half the town's 14,000 population is directly employed by the tuna industry, the indirect ties are much tighter. For instance, the sardine industry directly employs over 200 people. With festivals like the Tunarama, which has been going since 1962, and tour operations such as Matt Waller's, the buzz of the town mainly comes from tuna.

However, as the debate and politics around the tuna industry becomes ever more heated, there is increasingly a global distaste about the tuna. Much of it is media-fed, and with the release of the BBC documentary The End of the Line, food businesses such as the mega UK Prêt-a-manger now proudly announce that their tuna sandwiches are sourced from skipjack. More upscale enterprises such as Nobu have taken Bluefin sushi off their menu. The End of the Line presents a fair and grim portrait of the state of fish stocks. However the more sensational American documentary, The Cove, which won an Oscar, is drenched in hysterics against the Japanese - and as critics such as Emma Tom have pointed out, the rampant anthropomorphism which depicts dolphins as our childhood friends does little to address the complicated issues to do with who eats what, where.

There is no doubt that the Japanese are regularly fingered as the cause of tuna stocks' demise. Japan is of course central to the value of Bluefin tuna-they are what Issenberg calls 'the brokers of taste' (247). While Japanese companies are now huge vertically integrated entities, as Theodore Bestor strongly argues, one can't overlook the ways in which fish is linked to 'cuisine, work, gender and class identity' (37). Indeed he makes the point that fish in Japan lead what he calls 'the social life of seafood', whereby highly prized fish like tuna have 'cultural biographies'. So while the Japanese gave value and turned tuna into food, they also place tuna within an anthropomorphic cultural matrix (131).

Taste in tune with technology is what has fed the tuna industry since the 1950s. Others point to the greed of the tuna fishermen, however with the introduction of quotas they have invested large amounts in trying to achieve some semblance of sustainability. Over the last two decades there has been a seismic shift from fishing to farming, and while the basis for farming does sound strange-feed 
one fish to another - is it less disgusting and less devastating than feeding one animal to another, which has led to spectacular diseases in humans and animals, such as Bovine spongiform encephalopathy (BSE) or 'Mad Cow' disease? The questions raised by fish farming are numerous and I have only barely begun to articulate some of them. Pressing concerns about the state of wild-caught fisheries are not answered by a turn to fish farming, which indeed does eat into the ocean's ecology, and has substantial impacts on developing countries where fish farming has become a major source of income at the expense of feeding local populations.

Is Bluefin Tuna bad? Wouldn't it be nice if there were simple solutions? But the ones that are regularly trotted out tend to be simplistic and often racist. The fury at the 2010 meeting of CITES, the Convention on International Trade in Endangered Species in Qatar was directed at Libya and Japan. While it may have been Japan's lobbying that foreclosed a motion for a moratorium on the fishing of Northern Bluefin Tuna, the constant refrain of how bad Japan is begins to sound one-sided. While, as we've seen, most of the tuna in the world goes through Japan, much of it then goes on to the sushi bars around the world, and now increasingly to China. Japan has taught the rest of us to savour the taste of raw tuna flesh, and sushi bars have now become a sign of prosperity. But little attention is paid to the changing taste of and for tuna in Japan. Over the last decades the preference for wild tuna is slowly changing to the fattier taste of farmed. And equally the effects of global diets are being felt, as more and more Japanese kids prefer 'spag bol' to sushi.

To recall Guthman's point, we need to be aware of when 'moral sensibilities privilege environmental concerns over social ones'. In terms of our own areas of study, the complex and vexed questions of eating and human and non-human relations cannot be reduced to which species is most anthropomorphically endowed. If we are truly to advance a program of research, and of ethics, in eating we need to attend to both the singularity of species as well as our mutuality. This is a tough call, but necessary if we are to attend to the material conditions of what makes for emotional geographies and for whom. As researchers we are compelled to pay close attention to the faceted aspects of life, recognizing the multiplicity of what makes things feel. We may not like that the tuna men are businessmen, but they are also complex people with ties to places, fish, families, and communities and of course the sea. We do not know what tuna feel, and to speculate on that risks drawing us into the false security of sentimental comfort. We can chart their movements, physical and emotional, in price as well in national and affective value.

Travelling alongside the many actors, human and non-human, my tale of tuna, told from the stories of so many, may allow for an oblique but hopefully useful conception of the field of taste, in this instance, of the human-ocean entanglement, 
as it is being formed and re-formed in localities and regions seemingly outside of the mainstream. As Callon recounts, 'the growing complexity of industrialised society, [and] a level of sophistication due in large part to the movement of technosciences, are causing connections and interdependencies to proliferate' (12). But to extend his thoughts we need to attend to the emotional and affective forms of embodiment that are formed and re-formed within the materiality of hybrid forums. These complexities cannot be solved or resolved by (the often recognized male) experts working on their own alone in labs. As Graham-Gibson so clearly urge, experts and non-experts as well as humans and nonhumans must continually interact (628). Research as a clustering of objects, different experts, and contexts - an ecology of research - brings together very different actors to work at understanding large-scale issues through grounded and localised action.

Elspeth Probyn is Professor of Gender \& Cultural Studies, at the University of Sydney. She has taught media studies, sociology, and literature in Canada and the US. Her work focuses on questions of identity, material and cultural practices. She has theorized these through the grounded analyses of a wide-ranging set of areas: from eating, sex, emotions and affects, spatiality, and writing. Elspeth has published several books in these areas, including Sexing the Self, Outside Belongings, Carnal Appetites, Sexy Bodies and Blush: Faces of Shame (University of Minnesota Press and UNSW Press, 2005). Her current research brings together her interests in a new way-focusing on questions of food security, she bridges the paradigms of production and consumption through the study of fish, fishing and fishers globally and in regional Australia. This study, which elaborates a more-than-human perspective and methodology of fish-human communities, reveals alternative forms of globalization forged through routes of trade and technology, and brings into focus questions of ethnicity and gender.

\section{Works cited}

'About Dinko'. Lukin Fisheries Pty Ltd. Port Lincoln, South Australia. <http:// www.lukinfisheries.com.au/tuna.htm>. Accessed 26 October 2011

Appadurai, Arjun. 'Disjuncture and Difference in the Global Cultural Economy.' Public Culture 2.2 (1990): 1-24.

Allen, Robin. International Management of Tuna Fisheries: Arrangements, Challenges and a Way Forward. Rome: Food and Agriculture Organization of the United Nations, 2010.

Barclay, Kate. A Japanese Joint Venture in the Pacific: Foreign Bodies in Tinned Tuna. London: Routledge, 2008. 
-, and Koh Sunhui. 'Neo-liberal Reforms in Japan's Tuna Fisheries? A History of Government-Business Relations in the Food-Producing Sector.' Japan Forum 20.2 (2008): 139-170.

Barron, James. 'Warnings Don't Deter Lovers of Sushi.' The New York Times, 24 January 2008. <http://www.nytimes.com/2008/01/24/nyregion/24sushi. html $>$. Accessed 26 October 2011.

Bestor, Theodore C. Tsukiji: The Fish Market at the Center of the World. Berkeley: U of California P, 2004.

—. 'When Sushi Went Global.' <http://www.globalpolicy.org>. Accessed 22 April 2010.

Bourdieu, Pierre. Distinction: A Social Critique of the Judgment of Taste. Cambridge, Massachusetts: Cambridge UP, 1984.

Callon, Michel. 'Some Elements of a Sociology of Translation: Domestication of the Scallops and the Fishermen of St. Brieuc Bay.' Power, Belief and Action: A New Sociology of Knowledge? Ed. John Law. London: Routledge, 1986. 196223.

-. 'Why Virtualism Paves the Way to Political Impotence: A Reply to Daniel Miller's Critique of The Laws of the Markets.' Economic Sociology 7.2 (2005): 107-128.

Cook, Ian, et al. 'Geographies of Food: Following.' Progress in Human Geography. 30.5 (2006): 655-666.

Darwin, Charles. The Expression of the Emotions in Man and Animals. London: John Murray. See also <http://darwin-online.org.uk>. Accessed 8 June 2010 .

Fisher, M.F.K. The Art of Eating. NY: Wiley, 1990.

Gibson-Graham J.-K. 'Diverse Economies: Performative Practices for "other worlds".' Progress in Human Geography 32.5 (2008): 1-20.

Goodman, David. 'Agro-Food Studies in the "Age of Ecology": Nature, Corporeality, Bio-politics.' Sociologia Ruralis 39.1 (1999): 17-38.

Guthman, Julie. 'Can't Stomach It. How Michael Pollan et al Made Me Want to Eat Cheetos'. Gastronomica 7:3 (2007): 75-79.

- ' 'Fast Food/Organic Food: Reflexive Tastes and the Making of "Yuppie Chow"'. Social \& Cultural Geography 4:1 (2003): 46-58. 
- 'Neo-Liberalism and the Making of Food Politics in California.' Geoforum 39 (2008): 1171-1183.

Hardin, Garrett. 'The Tragedy of the Commons.' Science 162 (1968): 1243-1248.

Issenberg, Sasha. The Sushi Economy: Globalization and the Making of a Modern Delicacy. New York: Gotham Books, 2008.

Inns, Harold A. The Cod Fisheries: The History of an International Economy. 1940. Toronto: U of Toronto P, 1978.

'Japan Urges Industry-Wide Reduction of Tuna Effort.' World Fishing \& Aquaculture, 15 December 2010. <http://www.worldfishing.net/features101/ new-horizons/japan-urges-industry-wide-reduction-of-tuna-effort $>$. Accessed 15 July 2011.

Kurlansky, Mark. The Big Oyster. London: Jonathon Cape, 1996.

Marsden, Terry and Jonathon Murdoch. 'Introduction'. Between the Local and Global: Confronting Complexity in the Contemporary Agri-Food Sector. Ed. Terry Marsden and Jonathan Murdoch. Research in Rural Sociology and Development 12 (2006): 1-8.

Palasson, Gisli. 'Enskilment at Sea'. Man 29 (1994):901-927.

-, and Agnar Helgason. 'Figuring Fish and Measuring Men: The Individual Transferable Quota System in the Icelandic Cod Fishery.' Ocean and Coastal Management 28.1-3 (1995): 117-146.

Parasecoli, Fabio. 'Postrevolutionary Chowhounds' Gastronomica 3.3 (2003): 2939.

Potter, Emily. 'EcologicalCrisisand Australian Literary Representation.' Australian Humanities Review 37 (2005). <http://www.australianhumanitiesreview. org/archive/Issue-December-2005/potter.html>. Accessed 26 October 2011.

Pratt, Geraldine, and Victoria Rosner. 'Introduction: The Global \& the Intimate'. Women's Studies Quarterly 34.1/2 (2006): 13-24.

Probyn, Elspeth. 'The Anorexic Body'. Body Invaders: Panic Sex in America. Ed. Arthur and Marilouise Kroker. New York: St. Martin's Press, 1987.

- Carnal Appetites: FoodSexIdentities. London and New York: Routledge, 2000.

—. 'Eating for a Living: a Rhizo-Ethology of Bodies'. Cultural Bodies: Ethnography and Theory. Ed. Helen Thomas and Jamilah Ahmed. Oxford: Blackwell, 2004. 
-. 'In the Interests of Taste \& Place: Economies of Attachment'. The Global Intimate. Ed. Gerry Pratt and Victoria Rosner. New York: Columbia UP, 2012.

—. Outside Belongings. New York and London: Routledge, 1996.

Rich, Adrienne. Bread, Blood and Poetry. New York: Norton, 1985.

Stengers, Isabelle. 'Another Look: Relearning to Laugh'. Hypatia XV/4 (2000): 41-54.

-. 'Introductory Notes on an Ecology of Practices'. Cultural Studies Review 11.1 (2005):183-196.

Tom, Emma. 'Suffer the Dolphins, Just not Insufferable Mammal Snoots.' The Australian, 12 March 2010.

Whatmore, Sarah. 'Materialist Returns: Practising Cultural Geography in and for a More-Than-Human World.' Cultural Geographies 13 (2006): 600-609.

Winter, Michael. 'Embeddedness, the New Food Economy and Defensive Localism.' Journal of Rural Studies 19.1 (2003): 23-32. 